\title{
KAJIAN KOMPARASI PRODUKSI DAN PENDAPATAN USAHATANI KELAPA DALAM (Cocos nucifera Linn) BERDASARKAN TIPOLOGI LAHAN DI KABUPATEN INDRAGIRI HILIR
}

\author{
Sisca Vaulina \\ Staff Pengajar Fakultas Pertanian Universitas Islam Riau Pekanbaru \\ Email: siscavaulina@agr.uir.ac.id
}

\begin{abstract}
ABSTRAK
Perbedaan tipologi lahan berpengaruh terhadap potensi produksi Kelapa Dalam. Indragiri Hilir memiliki 4 tipologi lahan yakni (1) wilayah daratan (Kecamatan Keritang), (2) wilayah gambut pasang surut (Kecamatan Tempuling), (3) wilayah gambut pesisir (Kecamatan Gaung Anak Serka), (4) wilayah pesisir (Kecamatan Concong). Tujuan penelitian ini untuk menganalisis: (1) Usahatani Kelapa, mencakup teknologi budidaya, penggunaan faktor produksi, biaya, produksi, pendapatan dan efisiensi usahatani Kelapa Dalam berdasarkan tipologi lahan di Kabupaten Indragiri Hilir; (2) Faktor-faktor yang berpengaruh terhadap produksi Kelapa Dalam berdasarkan tipologi lahan di Kabupaten Indragiri Hilir. Penelitian ini menggunakan metode survey. Sampel ditentukan secara berjenjang (Multistage Area Sampling) dengan jumlah sampel 46 orang petani kelapa. Data dianalisis secara kualitatif dan kuantitatif dan menggunakan fungsi produksi Cobb-douglass. Hasil penelitian menunjukkan bahwa: (1) Produksi terbesar pada lahan pesisir $(4.350 / \mathrm{Kg} / \mathrm{panen} / \mathrm{ha})$, lahan gambut pasang surut $(3.100 / \mathrm{Kg} / \mathrm{panen} / \mathrm{ha})$, lahan daratan $(2.671 / \mathrm{Kg} / \mathrm{panen} / \mathrm{ha})$ dan lahan gambut pesisir $(2.003 / \mathrm{Kg} / \mathrm{panen} / \mathrm{ha})$. Pendapatan bersih usahatani kelapa dengan nilai tertinggi pada lahan pesisir (Kecamatan Concong) sebesar Rp Rp 1.250.818,53/panen. Sedangkan terendah pada lahan gambut pesisir (Kecamatan Gaung Anak Serka) sebesar Rp 111.434,47/panen. Nilai koefisien determinasi, untuk lahan daratan $R^{2}=0,99$; lahan gambut pasang surut $\mathrm{R}^{2}=0,96$; untuk lahan gambut pesisir $\mathrm{R}^{2}=0,64$ dan untuk lahan pesisir $\mathrm{R}^{2}=0,95$. Faktor yang berpengaruh signifikan terhadap produksi kelapa di lahan gambut pasang surut adalah lahan $(0,00)$, jumlah tanaman produktif $(0,01)$. Untuk lahan pesisir, factor yang berpengaruh signifikan terhadap produksi adalah terusi $(0,01)$, begitupula dengan lahan gambut pesisir $(0,03)$. Berbeda dengan lahan daratan, factor yang berpengaruh signifikan terhadap produksi adalah lahan $(0,03)$; tenaga kerja $(0,02)$; jumlah tanaman menghasilkan $(0,03)$, terusi $(0,03)$.
\end{abstract}

Kata kunci: Kelapa, Tipologi Lahan, Produksi, Pendapatan

\section{PENDAHULUAN}

Kabupaten Indragiri Hilir terletak pada dataran rendah atau pesisir timur dengan ketinggian < $5 \mathrm{~m}$ dpl. Daerah ini menjadi daerah rawa-rawa yang beriklim tropis basah dan memiliki struktur tanah yang berupa tanah organosol yaitu tanah gambut yang banyak mengandung bahan organik. Tanah didaerah ini cocok untuk tanaman perkebunan, salah satunya Kelapa Dalam. Produksi kelapa di kabupaten ini terdapat diseluruh kecamatan, sehingga kabupaten ini dikenal dengan julukan kabupaten "hamparan kelapa dunia".

Kabupaten Indragiri Hilir memiliki 4 tipologi lahan yakni (1) wilayah daratan (2) wilayah gambut pasang surut (3) wilayah gambut pesisir (4) wilayah pesisir (Mustofa dkk, 2016). Tipologi lahan berpengaruh terhadap potensi produksi dan karakteristik fisik tanaman 
Kelapa Dalam. Tanaman Kelapa Dalam dapat tumbuh, berkembang dan berproduksi dengan baik di daerah dataran sedang dengan ketinggian 100-500 m dpl (Hartawan dan Arif, 2016).

Perbedaan tipologi lahan menentukan produksi kelapa. Perbedaan tipologi lahan terdapat di beberapa kecamatan yaitu (1) Kecamatan Keritang untuk lahan daratan; (2) Kecamatan Tempuling untuk lahan gambut pasang surut; (3) Kecamatan Gaung Anak Serka untuk lahan gambut pesisir; dan (4) Kecamatan Concong untuk lahan pesisir. Secara rinci dapat dilihat pada Gambar 1.

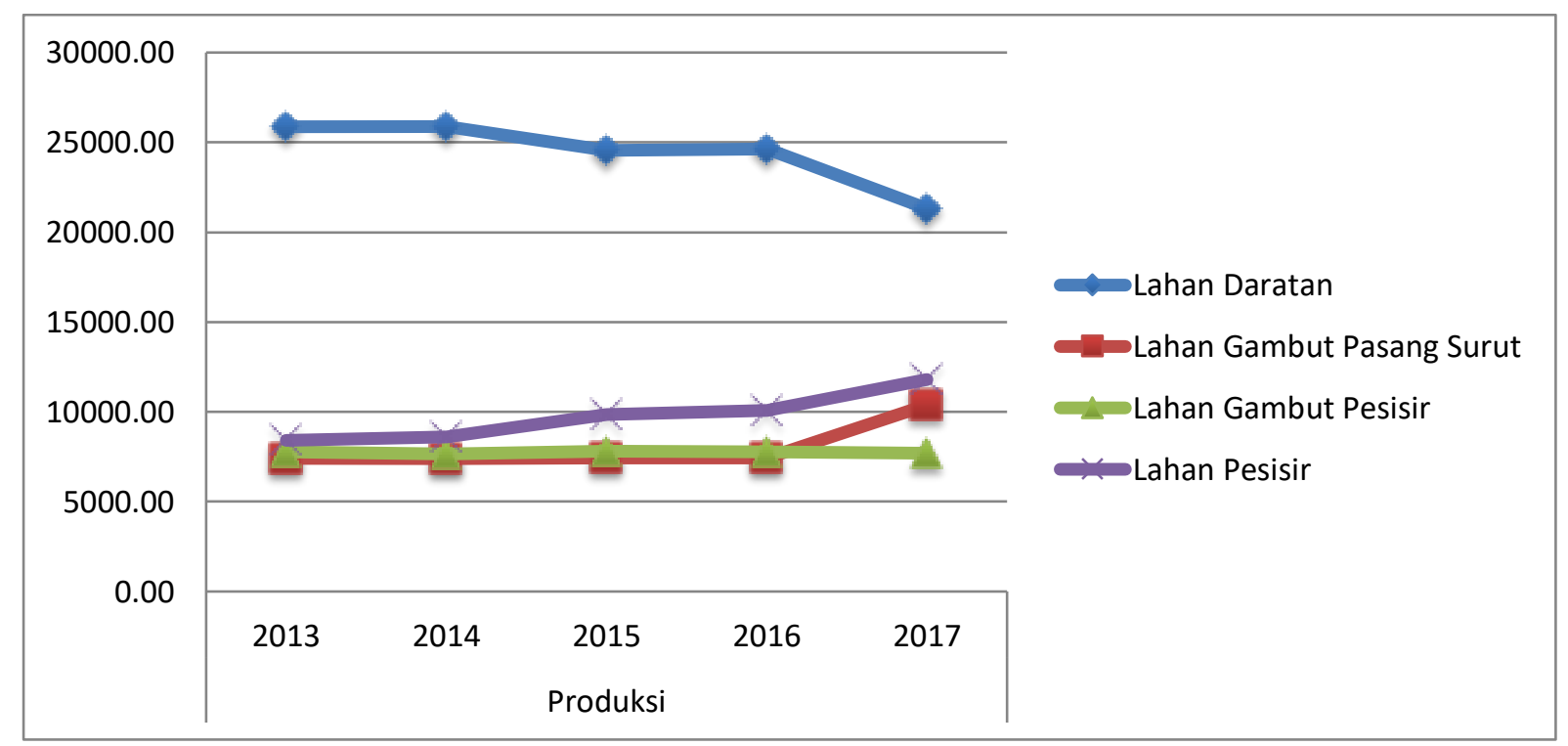

Sumber: BPS Kabupaten Indragiri Hilir, Tahun 2018 (Diolah)

Berdasarkan Gambar 1, perbedaan produksi mencerminkan bahwa kelapa yang diusahakan petani dengan luas lahan yang berbeda adalah sesuai dengan agroklimat daerahnya. Perbedaan produksi itu diduga karena perbedaan tipologi lahan. Tujuan penelitian untuk menganalisis: (1) Usahatani Kelapa Dalam, mencakup teknologi budidaya, biaya, produksi, pendapatan dan efisiensi usahatani Kelapa Dalam berdasarkan tipologi lahan di Kabupaten Indragiri Hilir; (2) Faktor-faktor apa saja yang berpengaruh terhadap produksi Kelana Dalam berdasarkan tipologi lahan di Kabupaten Indragiri Hilir

\section{METODE PENELITIAN}

Penelitian ini menggunakan metode survey. Diawali dengan menentukan lokasi-lokasi penelitian (kecamatan) berdasarkan tipologi lahan, yaitu (1) Wilayah daratan (Kecamatan Keritang); (2) Wilayah gambut pasang surut (Kecamatan Tempuling); (3) Wilayah gambut pesisir (Kecamatan Gaung Anak Serka); (4) Wilayah pesisir (Kecamatan Concong).

Sampel ditentukan secara purposive sampling, yakni berdasarkan pada tipologi lahan. Selanjutnya setiap tipologi lahan dipilih kecamatan-kecamatan, dan tiap kecamatan dipilih satu desa secara sengaja (berdasarkan tipe lahan). Jumlah sampel penelitian ini sebanyak 46 orang 
petani kelapa. Syarat tanaman sampel adalah tanaman milik rakyat dan umur tanaman 15-25 tahun. Ditentukannya umur tanaman kelapa 15-25 tahun karena umur tersebut merupakan umur produktif untuk tanaman kelapa. Selain itu, umur tanaman mempengaruhi produksi sehingga terlihat perbedaan produksi kelapa berdasarkan tipologi lahan. Lebih lengkap dapat dilihat pada Tabel 1.

Tabel 1. Kerangka Sampel Penelitian, 2018

\begin{tabular}{clllc}
\hline No & \multicolumn{1}{c}{ Tipologi Lahan } & \multicolumn{1}{c}{ Kecamatan } & \multicolumn{1}{c}{ Desa } & Sampel \\
\hline 1 & Wilayah Daratan & Keritang & Pancur & 6 \\
2 & Wilayah Gambut Pasang Surut & Tempuling & Tanjung Pidada & 5 \\
3 & Wilayah Gambut Pesisir & Gaung Anak Serka & Sungai Empat & 17 \\
4 & Wilayah Pesisir & Concong & Kampung Baru & 18 \\
\hline & & Jumlah & 46 \\
\hline
\end{tabular}

Berdasarkan Tabel 1, total sampel untuk 4 tipe lahan di Kabupaten Indragiri Hilir berjumlah 46 orang.

\section{Analisis Data}

Adapun analisis data yang digunakan dalam penelitian ini sebagai berikut:

\section{Usahatani Kelapa Dalam}

Penggunaan Faktor Produksi

Penggunaan faktor produksi digunakan analisis deskriptif, dengan cara memaparkan penggunaan faktor produksi di lokasi penelitian lalu membandingkannya dengan teori.

Biaya

Untuk mengetahui besarnya biaya yang dikeluarkan, digunakan perhitungan:

$$
\mathrm{TC}=\mathrm{FC}+\mathrm{VC}
$$

Keterangan:

$\mathrm{TC}=$ Total Cost $($ Biaya Total $)$

$\mathrm{FC}=$ Fixed Cost (Biaya Tetap)

$\mathrm{VC}=$ Variabel Cost (Biaya Variabel)

Produksi

Untuk produksi Kelapa Dalam digunakan analisis deskriptif, dengan cara memaparkan atau mendeskripsikan dan dibuat dalam bentuk tabel, produksi yang diperoleh petani disetiap tipologi lahan lalu membandingkannya dengan teori.

Pendapatan

Pendapatan bersih dapat diperoleh dengan cara mengurangkan pendapatan kotor (TR) terhadap biaya total (TC). Pendapatan kotor adalah jumlah unit output yang terjual (Y) 
dikalikan dengan harga output per unit. Dengan demikian, rumus pendapatan bersih sebagai berikut:

$$
\pi=\mathrm{TR}-\mathrm{TC}
$$

Keterangan:

$$
\begin{array}{ll}
\pi & =\text { Pendapatan Bersih } \\
\text { TR } & =\text { Pendapatan total (Total Revenue) } \\
\text { TC } & =\text { Biaya total (Total Cost) }
\end{array}
$$

Peralatan yang digunakan pada usahatani kelapa umumnya tidak habis dipakai untuk satu kali periode produksi (lebih dari satu tahun). Oleh karena itu, biaya peralatan yang dihitung sebagai komponen biaya produksi adalah nilai penyusutannya. Menghitung besarnya biaya penyusutan alat yang digunakan yakni metode garis lurus (straight line method) menurut Hernanto (1996), dengan rumus:

Keterangan:

$$
\mathrm{D}=\frac{\mathrm{C}-\mathrm{SV}}{\mathrm{UL}}
$$

D : Biaya penyusutan (Rp/unit/tahun)

C : Harga beli (Rp/unit/tahun)

SV : Nilai sisa $20 \%$ dari harga beli (Rp/unit/tahun)

UL : Masa pakai alat (tahun)

\section{Efisiensi}

Efisiensi usahatani Kelapa Dalam dianalisis menggunakan pendekatan Return Cost Ratio (RCR). Effendi dan Oktariza (2006) dalam Ngamel (2012), menjelaskan bahwa analisis Revenue Cost Ratio (R/C Rasio) merupakan alat analisis untuk melihat keuntungan relatif suatu usaha dalam satu tahun terhadap biaya yang dipakai dalam kegiatan tersebut. Kriteria yang digunakan dalam analisis $\mathrm{R} / \mathrm{C}$ rasio sebagai berikut:

- Jika nilai R/C rasio > 1 usaha dikatakan layak dan menguntungkan

- Jika nilai $\mathrm{R} / \mathrm{C}$ rasio < 1 usaha dikatakan tidak layak dan tidak menguntungkan

- Jika nilai $\mathrm{R} / \mathrm{C}$ rasio = 1 usaha dikatakan impas (tidak untung dan tidak rugi).

Dengan rumus sebagai berikut:

$$
\mathrm{RCR}=\frac{\mathrm{TR}}{\mathrm{TC}}
$$

Keterangan:

$\mathrm{RCR}=$ Return Cost Ratio

$\mathrm{TR}=$ Pendapatan kotor $(\mathrm{Kg} / \mathrm{Panen} / \mathrm{Ha})$

$\mathrm{TC}=$ Total biaya produksi $(\mathrm{Kg} / \mathrm{Panen} / \mathrm{Ha})$

Dengan kriteria:

RCR $>1=$ Berarti usahatani Kelapa Dalam menguntungkan

RCR $<1=$ Berarti usahatani Kelapa Dalam tidak menguntungkan

$\mathrm{RCR}=1=$ Berarti usahatani Kelapa Dalam berada pada titik impas

102 | Kajian Komparasi Produksi Dan Pendapatan Usahatani Kelapa Dalam (Cocos Nucifera Linn) Berdasarkan Tipologi Lahan Di Kabupaten Indragiri Hilir 


\section{Faktor-Faktor yang Mempengaruhi Produksi Kelapa Dalam}

Fungsi Cobb-Douglas dalam penelitian ini digunakan untuk mengetahui faktor-faktor yang mempengaruhi produksi kelapa dalam. Model ini dipilih berdasarkan pertimbangan bahwa; (1) Model fungsi Cobb-Douglas adalah model yang lazim digunakan dalam penelitian ekonomi pertanian karena sifatnya yang praktis dan mudah ditrasformasikan ke dalam bentuk nonlinear (Soekartawi,2003); (2) Menurut Gujarati (2001) koefisien regresi yang ditunjukkan oleh fungsi produksi Cobb-Douglas merupakan elastisitas faktor produksi dan memberikan informasi mengenai pengaruh skala terhadap hasil (return to scale). Pada dasarnya fungsi tersebut berasal dari regresi yang persamaan umumnya dapat ditulis sebagai berikut:

$$
\mathrm{Y}=\mathrm{f}(\mathrm{x})
$$

Keterangan:

$\mathrm{Y}=$ variabel yang dipengaruhi (variabel terikat)

$\mathrm{x}=$ variabel yang mempengaruhi (variabel bebas)

Fungsi produksi Cobb-Douglas secara matematis dapat ditulis sebagai berikut:

$$
\mathrm{Y}_{\mathrm{i}}=\beta_{0} \beta_{1}
$$

Agar fungsi produksi Cobb-Douglas dapat diestimasi dengan metode OLS maka diubah ke dalam bentuk logaritma natural sebagai berikut:

$$
\operatorname{Ln} Y=\operatorname{Ln} a+b_{1} \operatorname{Ln} X_{1}+b_{2} \operatorname{Ln} X_{2}+b_{3} \operatorname{Ln} X_{3}+b_{4} \operatorname{Ln} X_{4}+u
$$

Keterangan:

$\mathrm{Y}=$ Produksi kelapa dalam $(\mathrm{Kg} / \mathrm{Panen} / \mathrm{Ha})$

$\mathrm{X}_{1}=\operatorname{Lahan}(\mathrm{Ha})$

$\mathrm{X}_{2}=$ Jumlah tanaman produktif (Pohon/Ha)

$\mathrm{X}_{3}=$ Tenaga kerja $(\mathrm{HOK} / \mathrm{Ha})$

$\mathrm{X}_{4}=$ Terusi $(\mathrm{Kg} / \mathrm{Ha})$

\section{Pengujian Hipotesis secara Parsial (Uji T)}

Pengujian secara parsial menggunakan Uji T yang merupakan uji pengaruh signifikan variabel independen terhadap variabel dependen secara individual. Uji signifikansi adalah prosedur di mana hasil sampel digunakan untuk menentukan keputusan untuk menerima atau menolak Ho berdasarkan nilai uji statistik yang diperoleh dari data. Prosedur Uji T adalah sebagai berikut (Widarjono, 2007):

1. Membuat hipotesa nol (Ho) dan hipotesa alternatif (Ha)

2. Menghitung t dengan rumus:

$$
t_{\text {hit }}=\frac{b_{1}-b}{S_{b}}
$$

103 | Kajian Komparasi Produksi Dan Pendapatan Usahatani Kelapa Dalam (Cocos Nucifera Linn) Berdasarkan Tipologi Lahan Di Kabupaten Indragiri Hilir 
Keterangan: bi $=$ Koefisien bebas ke- $i$

$\mathrm{b}=$ Nilai hipotesis nol

$\mathrm{Sb}=$ Simpangan baku (standar deviasi) dari variabel bebas ke- $i$

3. Mencari nilai kritis $\mathrm{t}$ dari tabel $\mathrm{t}$ dengan $\mathrm{df}=\mathrm{n}-\mathrm{k}$ dan $\alpha$ yang tertentu

4. Keputusan untuk menerima atau menolak Ho didasarkan pada perbandingan $t$ hitung dan $t$ tabel (nilai kritis).

Jika: $t$ hitung > t tabel, maka Ho ditolak dan Hi diterima

$\mathrm{t}$ hitung $<\mathrm{t}$ tabel, maka Ho diterima dan Hi ditolak

\section{Pengujian Hipotesis secara Serempak (Uji F)}

Pengujian secara serempak menggunakan Uji F. Uji F bertujuan untuk menguji pengaruh semua variabel independen terhadap variabel dependen secara bersama-sama. Prosedur pengujian uji $\mathrm{F}$ adalah sebagai berikut:

1. Membuat hipotesa nol (Ho) dan hipotesa alternatif (Ha)

2. Menghitung nilai F.hitung dengan rumus:

$$
\mathrm{F}=\frac{\mathrm{R}^{2} /(\mathrm{k}-1)}{\left(1-\mathrm{R}^{2}\right) /(\mathrm{n}-\mathrm{k})} \ldots \ldots \ldots(9)
$$

Keterangan: $\mathrm{R}^{2}=$ Koefisien determinasi

$\mathrm{k}=$ Jumlah variabel independen

$\mathrm{n}=$ Jumlah sampel

3. Mencari nilai kritis ( $\mathrm{F}$ tabel); df (k-1, n-k).

Dimana: $\mathrm{k}=$ jumlah parameter termasuk intersep.

4. Keputusan untuk menerima atau menolak Ho didasarkan pada perbandingan $\mathrm{F}$ hitung dan $\mathrm{F}$ tabel.

Jika: F hitung > F tabel, maka Ho ditolak dan Hi diterima

$\mathrm{F}$ hitung $<\mathrm{F}$ tabel, maka Ho diterima dan Hi ditolak.

Gujarati (1995) koefisien determinasi adalah untuk mengetahui seberapa besar persentase sumbangan variabel bebas terhadap variabel terikat yang dapat dinyatakan dalam persentase. Besarnya persentase pengaruh semua variabel independen terhadap nilai variabel dependen dapat diketahui dari besarnya koefisien determinasi $\left(\mathrm{R}^{2}\right)$ persamaan regresi. 


\section{HASIL DAN PEMBAHASAN}

\section{Usahatani Kelapa Dalam (Penggunaan Faktor Produksi, Biaya, Produksi, Pendapatan dan Efisiensi)}

Sebagian besar petani kelapa pada sampel penelitian menggunakan bibit lokal. Namun, ada juga petani yang membeli bibit kelapa ke kecamatan Pengalihan Enok dan Enok Dalam. Sistem penanaman tanaman kelapa umumnya menggunakan baris lurus memanjang, jumlah pohon per baris tergantung pada daerah masing-masing. Ada petani yang menetapkan dalam 1 baris kelapa terdapat 27-28 pohon kelapa, namun ada juga yang menetapkan 1 baris menjadi 30 pohon kelapa. Bagi sebagian petani, baris pada pohon kelapa ini dijadikan sebagai dasar untuk menjual tanah mereka.

Pengendalian hama dan penyakit, petani keempat tipe lahan menggunakan terusi, NPK dan garam. Namun, masih terdapat petani yang tidak menggunakan pupuk, terutama di lahan pesisir. Begitupula dengan pestisida, petani menggunakan pestisida tidak kontiniu namun seperlunya saja. Jumlah pohon kelapa per hektar juga bervariasi, tergantung pada jarak tanam. Umumnya jumlah pohon di daerah penelitian yakni dalam satu hektar terdapat 150 pohon kelapa hingga 255 pohon kelapa. Berdasarkan pada Menteri Pertanian Republik Indonesia (2014), jumlah tanaman kelapa dalam 1 hektar terdapat 106 pohon kelapa hingga 175 pohon kelapa. Dengan demikian dapat disimpulkan bahwa sebagian petani menanam kelapa sudah sesuai dengan ketentuan Menteri Pertanian Republik Indonesia.

Periode panen kelapa dalam satu tahun pemetikan dilakukan minimal 4 kali (tiap tiga bulan), atau 3 kali (tiap empat bulan), atau maksimal 6 kali (tiap 2 bulan). Kriteria buah siap panen adalah sebagai berikut: (1) buah kelapa umumnya siap matang panen umurnya 11-13 bulan; (2) warna kulit buah kecoklat-coklatan (umumnya); (3) apabila buah diguncang air Kelapanya berbunyi nyaring.

\section{B. Penggunaan Faktor Produksi} Lahan

Lahan usahatani kelapa pada empat tipologi lahan umumnya lahan milik sendiri. Keadaan lahan dan luas lahan akan mempengaruhi besarnya jumlah produksi dan penggunaan tenaga kerja. Secara rinci dapat dilihat pada Tabel 2.

Tabel 2. Luas Kepemilikan Lahan (Ha) Petani Kelapa di Kabupaten Indragiri Hilir, Tahun 2018

\begin{tabular}{cccc}
\hline No & Luas Lahan $(\mathrm{Ha})$ & Jumlah Petani (Jiwa) & Persentase $(\%)$ \\
\hline 1 & $<1,0$ & 4 & 8,69 \\
2 & $1,0-1,9$ & 15 & 32,61 \\
3 & $2,0-2,9$ & 14 & 30,43 \\
4 & $3,0-3,9$ & 5 & 10,87 \\
5 & $4,0-4,9$ & 4 & 8,69
\end{tabular}

105 | Kajian Komparasi Produksi Dan Pendapatan Usahatani Kelapa Dalam (Cocos Nucifera Linn) Berdasarkan Tipologi Lahan Di Kabupaten Indragiri Hilir 


\begin{tabular}{rrrr}
6 & $5,0-5,9$ & 1 & 2,18 \\
7 & $6,0-6,9$ & 2 & 4,35 \\
8 & $7,0-7,9$ & 1 & 2,18 \\
\hline & Jumlah & 46 & 100,00 \\
\hline
\end{tabular}

Berdasarkan Tabel 2, bahwa lahan yang dimiliki oleh petani kelapa memiliki luas lahan yang berbeda-beda. Fakta di lapangan menyatakan bahwa luas lahan dari sampel petani kelapa memiliki luas lahan terluas pada luas $1,0-1,9$ ha dengan jumlah 15 orang petani $(32,61 \%)$. Lahan kelapa atau biasa yang disebut dengan kebun kelapa yang dimiliki petani umumnya berada jauh dari tempat tinggal mereka, jarak tempuh petani \pm 10 sampai $\pm 300 \mathrm{~km}$, dengan menggunakan motor, sampan atau pompong. Sementara itu, untuk lahan yang $<0,1$ ha umumnya terletak di pekarangan rumah atau terletak tidak jauh dari tempat tinggal mereka. Ruauw, dkk (2011) di desa Tolombukan kecamatan Pasan kabupaten Minahasa Tenggara, sampel petani kelapa umumnya memiliki luas lahan $<1$ ha, karena petani sampel telah membagikan sebagian lahan yang diusahakan kepada anak-anaknya yang telah berkeluarga. Kondisi ini berbeda dengan di kabupaten Indragiri Hilir, umumnya petani mengelola kebun kelapa bersama-sama dengan anak-anak atau keluarga besar mereka.

Tenaga kerja

Penggunaan tenaga kerja pada usahatani kelapa terdiri dari tenaga kerja dalam keluarga dan tenaga kerja luar keluarga. Tahapan tenaga kerja terdiri atas: (1) pembersihan kebun atau penyiangan kebun kelapa; (2) pemupukan dan pengendalian hama penyakit; (3) panen; dan (4) pengangkutan. Masa kerja pembersihan kebun berkisar antara 7-8 jam masa pengerjaan, dimulai pagi pada pukul 07.00-11.00 wib dan siang pada pukul 14.00-17.00 wib. Namun, ada juga petani yang mengerjakan hanya 3-4 jam pengerjaan dalam satu hari.

Pupuk

Petani yang menggunakan pupuk Urea, terusi, NPK, KCL umumnya petani yang memiliki lahan yang luas. Tidak semua kecamatan petani kelapa menggunakan pupuk, contohnya di Kecamatan Concong (lahan pesisir), karena jika diberi pupuk maka pupuk tersebut akan ikut hanyut dengan pasang air laut.

\section{Biaya Usahatani}

Dalam penelitian ini biaya tetap yaitu biaya penyusutan. Biaya penyusutan alat dihitung berdasarkan kepemilikan alat pertanian petani. Peralatan yang akan dihitung penyusutannya adalah parang, cangkul, linggis, ambung, solak, handsprayer, pengait, dan tojok. Rata-rata usia ekonomis peralatan tersebut 3 tahun, kecuali solak yang memiliki umur ekonomis 5 tahun. 
Biaya variabel terdiri dari biaya tenaga kerja; bibit, pupuk dan pestisida. Untuk tenaga kerja luar keluarga, upah yang diberikan untuk membersihkan kebun atau penyiangan kebun yaitu sebesar Rp 1.500/pohon-Rp 3.000/pohon. Tenaga kerja yang digunakan yaitu tenaga kerja wanita dan tenaga kerja pria. Rata-rata harga bibit Rp 500/batang-Rp 4.000/batang. Usahatani kelapa umumnya petani menggunakan pupuk NPK, terusi, dan juga menggunakan garam. Sementara itu, untuk pestisida yang digunakan yaitu herbisida dan decis. Pupuk dan pestisida yang diberikan petani saat 3 bulan sekali atau 4 bulan sekali atau 6 bulan sekali dan 1 tahun sekali.

Tabel 3. Rata-Rata Biaya Usahatani Petani Kelapa Dalam Berdasarkan Tipologi Lahan, Tahun 2018

\begin{tabular}{lcrrr}
\hline $\mathrm{N}$ & Jenis Biaya (Rp) \\
$\mathrm{o}$ & & \multicolumn{4}{c}{ Tipologi Lahan } \\
\cline { 2 - 5 } & $\begin{array}{c}\text { Lahan Daratan } \\
\text { (Keritang) }\end{array}$ & $\begin{array}{c}\text { Lahan } \\
\text { Gambut } \\
\text { Pasang Surut } \\
\text { (Tempuling) }\end{array}$ & $\begin{array}{c}\text { Lahan } \\
\text { Gambut } \\
\text { Pesisir } \\
\text { (GAS) }\end{array}$ & $\begin{array}{c}\text { Lahan Pesisir } \\
\text { (Concong) }\end{array}$ \\
\hline Biaya Tetap & & & & \\
$1 \quad$ Biaya Penyusutan & $233.324,00$ & $295.417,00$ & $248.392,00$ & $651.742,00$ \\
$\quad$ Jumlah & $233.324,00$ & $295.417,00$ & $248.392,00$ & $651.742,00$ \\
Biaya Tidak Tetap & & & & \\
$1 \quad$ Bibit (Batang) & $452.785,71$ & $106.200,00$ & $319.264,71$ & $1.181 .715,79$ \\
$2 \quad$ Pupuk (terusi) & $27.857,14$ & $146.000,00$ & $158.235,29$ & $115.789,47$ \\
$3 \quad$ Pestisida & $220.000,00$ & $266.000,00$ & $195.294,12$ & - \\
$4 \quad$ Tenaga kerja & $1.068 .571,43$ & $953.750,00$ & $569.779,41$ & $1.149 .934,21$ \\
$\quad$ Jumlah & $1.769 .214,28$ & $1.471 .950,00$ & $1.242 .573,53$ & $2.447 .439,47$ \\
\hline Total Biaya & $\mathbf{2 . 0 0 2 . 5 3 8 , 2 8}$ & $\mathbf{1 . 7 6 7 . 3 6 7 , 0 0}$ & $\mathbf{1 . 4 9 0 . 9 6 5 , 5 3}$ & $\mathbf{3 . 0 9 9 . 1 8 1 , 4 7}$ \\
\hline
\end{tabular}

Pada Tabel 3, dari empat tipologi lahan, lahan pesisir membutuhkan biaya yang lebih besar dibandingkan lahan-lahan yang lainnya. Perbedaan yang mencolok terlihat pada penggunaan bibit, petani di lahan pesisir (Kecamatan Concong) umumnya menggunakan bibit unggul. Sementara itu, untuk lahan gambut pesisir (Keccamatan Gaung Anak Serka) membutuhkan biaya yang paling kecil dibandingkan dengan lahan-lahan yang lainnya.

\section{Produksi dan Pendapatan}

Produksi kelapa yang dijadikan objek dalam penelitian ini adalah kelapa dalam bentuk butiran. Jika dilihat dari produksi pada empat tipe lahan, maka secara berturut-turut produksi terbesar untuk kelapa yaitu lahan pesisir $(4.350 / \mathrm{Kg} / \mathrm{panen} / \mathrm{ha})$, lahan gambut pasang surut (3.100/Kg/panen/ha), lahan daratan $(2.671 / \mathrm{Kg} / \mathrm{panen} / \mathrm{ha})$ dan lahan gambut pesisir (2.003/Kg/panen/ha). Secara rinci dapat dilihat pada Tabel 4. 
Tabel 4. Produksi, Harga, Penerimaan dan Pendapatan Bersih Usahatani Kelapa Dalam Berdasarkan Tipologi Lahan, Tahun 2018

\begin{tabular}{llrrrr}
\hline $\mathrm{N}$ & \multicolumn{1}{c}{ Keterangan } & \multicolumn{4}{c}{ Tipologi Lahan } \\
\cline { 2 - 6 } $\mathrm{o}$ & $\begin{array}{c}\text { Lahan Daratan } \\
\text { (Keritang) }\end{array}$ & $\begin{array}{c}\text { Lahan } \\
\text { Gambut } \\
\text { Pasang Surut } \\
\text { (Tempuling) }\end{array}$ & $\begin{array}{c}\text { Lahan Gambut } \\
\text { Pesisir } \\
\text { (GAS) }\end{array}$ & $\begin{array}{c}\text { Lahan Pesisir } \\
\text { (Concong) }\end{array}$ \\
\hline 1 & Produksi (Kg) & 2.671 & 3.100 & 2.003 & 4.350 \\
2 & Harga (Rp) & 1.000 & 1.300 & 800 & 1.000 \\
3 & Penerimaan (Rp/Kg) & $2.671 .000,00$ & $4.030 .000,00$ & $1.602 .400,00$ & $4.350 .000,00$ \\
4 & Biaya (Rp) & $2.002 .538,28$ & $1.767 .367,00$ & $1.490 .965,53$ & $3.099 .181,47$ \\
5 & Pendapatan Bersih & $668.461,72$ & $2.262 .633,00$ & $111.434,47$ & $1.250 .818,53$ \\
& (Rp/Kg) & & & 1,07 & 1,40 \\
6 & Efisiensi & 1,33 & 2,28 & & \\
\hline
\end{tabular}

Berdasarkan Tabel 4, penerimaan usahatani kelapa dengan nilai tertinggi pada lahan pesisir (Kecamatan Concong) sebesar Rp 4.350.000,00/panen, dan pendapatan bersih Rp 1.250.818,53/panen. Sedangkan pendapatan terendah pada lahan gambut pesisir (Kecamatan Gaung Anak Serka) sebesar Rp 1.602.400,00/panen dan pendapatan bersih Rp 111.434,47/panen. Rendahnya pendapatan yang diterima petani karena harga kelapa yang berfluktuasi. Pada saat penelitian, harga kelapa sedang murah.

Hasil penelitian Pangkey, dkk (2016), pendapatan usahatani kelapa di Kecamatan Sinonsayang berkisar antara Rp 3.200.00/bulan - Rp 4.106.000/bulan. Dapat disimpulkan bahwa pendapatan petani Kelapa Dalam di Kabupaten Indragiri Hilir tergolong rendah. Supadi dan Nurmanaf (2006), rendahnya penghasilan yang diperoleh dari kelapa menyebabkan petani tidak memiliki modal untuk memelihara kebun secara intensif, apalagi menggarap lahan perkebunan secara optimal maupun mengolah hasil. Meskipun begitu, Dongoran (2013), usahatani kelapa memiliki peluang ekonomi yang sangat baik untuk dikembangkan dalam upaya peningkatan ekonomi kerakyatan.

Dari sisi pendapatan usahatani belum mampu menunjang kehidupan keluarga petani secara layak. Hasil studi yang dilaksanakan disentra-sentra produksi kelapa di Indonesia menunjukkan bahwa kehidupan keluarga petani kelapa secara umum sampai saat ini masih berada dibawah garis kemiskinan (Tarigans, 2002). Bavappa et al. (1995) proporsi pendapatan petani kelapa di Indonesia sangat kecil hanya 20\% dari total pendapatannya. Tarigans, (2005), kenyataan demikian, menunjukkan peranan ekonomi komoditas kelapa belum optimal bila dilihat dari segi pendapatan petani, pemenuhan kebutuhan bahan baku industri dan sumber devisa negara secara nasional.

108 | Kajian Komparasi Produksi Dan Pendapatan Usahatani Kelapa Dalam (Cocos Nucifera Linn) Berdasarkan Tipologi Lahan Di Kabupaten Indragiri Hilir 


\section{Efisiensi}

Berdasarkan pada Tabel 4, diketahui bahwa efisiensi usahatani Kelapa Dalam sebesar 1,33 pada lahan daratan, 2,28 pada lahan gambut pasang surut, 1,07 lahan gambut pesisir dan 1,40 pada lahan pesisir. Artinya bahwa usahatani kelapa masih layak dan menguntungkan untuk dikembangkan pada berbagai tipe lahan di Kabupaten Indragiri Hilir. Nilai yang sama juga terdapat di Desa Malonas Kecamatan Dampelas Kabupaten Donggala (Yanti dkk, 2015), angka R/C sebesar 2,45 artinya bahwa setiap pengeluaran biaya Rp 1.000 akan diperoleh penerimaan sebesar Rp 2.450.

\section{Faktor-Faktor yang Mempengaruhi Produksi Kelapa Dalam pada Berbagai Tipologi Lahan}

Tanaman kelapa dalam memiliki syarat tumbuh dengan toleransi yang relative luas tetapi berkembang optimal pada kondisi tanah yang memiliki fraksi tanah yang banyak dan dalam, serta pH antara 5,5 sampai dengan 8 (Abdurachman dan Mulyani, 2003). Hartawan dan Sarjono (2016), ekologi lahan berpengaruh nyata terhadap potensi produksi da karakteristik fisik tanaman kelapa dalam. Tanaman kelapa dalam dapat tumbuh, berkembang dan berproduksi dengan baik di daerah dataran sedang dengan ketinggian 100-500 m dpl.

Tabel 5. Hasil Perhitungan Fungsi Produksi Cobb-Douglass Kelapa Dalam Berdasarkan Tipologi Lahan di Kabupaten Indragiri Hilir, Tahun 2018

\begin{tabular}{|c|c|c|c|c|c|}
\hline \multirow[t]{2}{*}{ No } & \multirow[t]{2}{*}{ Uraian } & \multicolumn{4}{|c|}{ Tipologi Lahan } \\
\hline & & $\begin{array}{c}\text { Lahan } \\
\text { Daratan }\end{array}$ & $\begin{array}{l}\text { Lahan Gambut } \\
\text { Pasang Surut }\end{array}$ & $\begin{array}{c}\text { Lahan Gambut } \\
\text { Pesisir }\end{array}$ & Lahan Pesisir \\
\hline 1 & R Square & 0,99 & 0,96 & 0,64 & 0,95 \\
\hline 2 & Uji F & 6,32 & 118,36 & 9,05 & 17,28 \\
\hline 3 & $\mathrm{Uji} \mathrm{T}$ & & & & \\
\hline & $\mathrm{X}_{1}$ & 0,03 & 0,00 & 0,54 & 0,70 \\
\hline & $\mathrm{X}_{2}$ & 0,02 & 0,23 & 0,14 & 0,09 \\
\hline & $\mathrm{X}_{3}$ & 0,03 & 0,01 & 0,56 & 0,42 \\
\hline & $\mathrm{X}_{4}$ & 0,03 & 0,054 & 0,03 & 0,01 \\
\hline
\end{tabular}

\section{Lahan Daratan (Kecamatan Keritang)}

Berdasarkan hasil penelitian, maka diperoleh persamaan fungsi produksi CobbDouglass untuk kelapa dalam di lahan daratan, sebagai berikut:

$$
\operatorname{LnQ}=\operatorname{Ln}(18,03)+(70,88) \operatorname{LnX}_{1}+33,29 \operatorname{Ln} X_{2}+46,48 \operatorname{Ln} X_{3}+(55,79) \operatorname{LnX}_{4}
$$

Sehingga fungsi produksi dapat diperoleh sebagai berikut:

$$
\operatorname{LnQ}=18,03 \mathrm{X}_{1}{ }^{(70,88)} \mathrm{X}_{2}{ }^{33,29} \mathrm{X}_{3}^{46,48} \mathrm{X}_{4}{ }^{(55,79)}
$$

Berdasarkan Tabel 5 diperoleh nilai Fhitung sebesar 6,32 pada lahan daratan dengan tingkat kepercayaan 95\% $(\alpha=0,05)$. Disini bisa dilakukan pendekatan p-value atau sig., 
dimana sig. $<\alpha$, maka $\mathrm{H}_{0}$ ditolak dan $\mathrm{H}_{1}$ diterima artinya secara bersama-sama (serempak) variabel lahan; jumlah tanaman produktif; tenaga kerja dan terusi berpengaruh signifikan terhadap produksi kelapa dalam di kabupaten Indragiri Hilir. Selain itu, diperoleh informasi juga bahwa variabel lahan $\left(\mathrm{X}_{1}\right)$; tenaga kerja $\left(\mathrm{X}_{2}\right)$; jumlah tanaman produktif $\left(\mathrm{X}_{3}\right)$; dan terusi $\left(\mathrm{X}_{4}\right)$ berpengaruh terhadap produksi kelapa di lahan daratan.

\section{Lahan Gambut Pasang Surut (Kecamatan Tempuling)}

Berdasarkan hasil penelitian, maka diperoleh persamaan fungsi Cobb-Douglass untuk kelapa dalam di lahan gambut pasang surut, sebagai berikut:

$$
\operatorname{LnY}=\operatorname{Ln} 192,98+2.821,98 \operatorname{LnX}_{1}+18,85 \operatorname{LnX}_{2}+(8,33) \operatorname{LnX}_{3}+(31,92) \operatorname{LnX}_{4}
$$

Sehingga fungsi produksi dapat diperoleh sebagai berikut:

$$
\mathrm{Y}=192,98 \mathrm{X}_{1}{ }^{2.821,98} \mathrm{X}_{2}{ }^{18,85} \mathrm{X}_{3}{ }^{(8,33)} \mathrm{X}_{4}{ }^{(31,92)}
$$

Berdasarkan Tabel 5, nilai koefisien determinasi $\left(\mathrm{R}^{2}\right)$ sebesar 0,96 menunjukkan bahwa 96\% variasi lahan; jumlah tanaman produktif; tenaga kerja; dan pupuk mampu menjelaskan variasi produksi kelapa dalam, sedangkan sisanya 5\% dijelaskan oleh variabel lain yang tidak diteliti. Dengan kata lain, masih ada beberapa input produksi antara lain penggunaan bibit unggul dan pestisida yang dapat menjelaskan variasi produksi kelapa dalam. Damanik (2007), ketersediaan sumberdaya lahan dan iklim yang sesuai serta ketersediaan tenaga kerja dan teknologi begitu juga pangsa pasar, menjadi keunggulan untuk peningkatan produksi kelapa persatuan luas pengelolaan.

Pada Tabel 5, variabel lahan $\left(\mathrm{X}_{1}\right)$ dan jumlah tanaman produktif $\left(\mathrm{X}_{3}\right)$ berpengaruh signifikan terhadap produksi kelapa, sedangkan variabel tenaga kerja $\left(\mathrm{X}_{2}\right)$ dan terusi $\left(\mathrm{X}_{4}\right)$ tidak berpengaruh signifikan terhadap produksi tanaman kelapa di lahan gambut pasang surut. Hasil penelitian Damanik dan Dedi (2009) pada lahan gambut di Kecamatan Tempuling, Kabupaten Indragiri Hilir analisis fungsi produksi dengan tiga input faktor (bibit, pupuk dan tenaga kerja) menunjukkan bahwa posisi petani sebagai produsen berada pada kondisi yang artinya pemakaian input bibit, pupuk dan tenaga kerja masih dapat ditingkatkan untuk mencapai tingkat keuntungan yang maksimal. Sementara itu, Vaulina dan Saipul (2015), di Kabupaten Indragiri Hilir, luas lahan, jumlah tanaman menghasilkan, dan tenaga kerja merupakan faktor yang mempengaruhi produksi kelapa.

\section{Lahan Gambut Pesisir (Kecamatan Gaung Anak Serka)}

Berdasarkan hasil penelitian, maka diperoleh nilai untuk kelapa dalam di lahan gambut pesisir, sebagai berikut:

$$
\operatorname{LnY}=\operatorname{Ln}(91,86)+36,085 \operatorname{LnX} 1+(19,16) \operatorname{LnX}_{2}+(227,15) \operatorname{LnX}_{3}+199,66 \operatorname{LnX}_{4}
$$


Sehingga fungsi produksi dapat diperoleh sebagai berikut:

$$
\operatorname{LnY}=(91,86) \mathrm{X}_{1}{ }^{36,085} \mathrm{X}_{2}{ }^{(19,16)} \mathrm{X}_{3}{ }^{(227,15)} \mathrm{X}_{4}{ }^{199,66}
$$

Berdasarkan Tabel 5 diperoleh nilai $F_{\text {hitung }}$ sebesar 9,05 pada lahan gambut pesisir dengan tingkat kepercayaan 95\% $(\alpha=0,05)$. Disini bisa dilakukan pendekatan p-value atau sig., dimana sig. $<\alpha$, maka $\mathrm{H}_{0}$ ditolak dan $\mathrm{H}_{1}$ diterima artinya secara bersama-sama (serempak) variabel lahan; jumlah tanaman produktif; tenaga kerja dan terusi berpengaruh signifikan terhadap produksi kelapa dalam di kabupaten Indragiri Hilir. Dengan kata lain bahwa tanpa adanya input produksi akan mengakibatkan terhentinya proses produksi dan hasil produksi sama dengan nol. Berdasarkan Tabel 4, variabel terusi $\left(\mathrm{X}_{4}\right)$ berpengaruh signifikan terhadap produksi kelapa, sedangkan variabel lahan $\left(\mathrm{X}_{1}\right)$; jumlah tanaman produktif $\left(\mathrm{X}_{3}\right)$; dan tenaga kerja $\left(\mathrm{X}_{2}\right)$ tidak berpengaruh signifikan terhadap produksi tanaman kelapa di lahan gambut pesisir.

\section{Lahan Pesisir (Kecamatan Concong)}

Berdasarkan hasil penelitian, maka diperoleh persamaan Cobb-Douglass untuk kelapa dalam di lahan pesisir, sebagai berikut:

$$
\mathrm{LnQ}=\operatorname{Ln} 1.164,47+211,49 \operatorname{LnX} 1+(50,30) \operatorname{LnX}_{2}+2,50 \operatorname{LnX}_{3}+137,78 \operatorname{LnX}_{4}
$$

Sehingga fungsi produksi dapat diperoleh sebagai berikut:

$$
\mathrm{LnQ}=1.164,47 \mathrm{X}_{1}{ }^{211,49} \mathrm{X}_{2}{ }^{(50,30)} \mathrm{X}_{3}{ }^{2,50} \mathrm{X}_{4}{ }^{137,78}
$$

Berdasarkan Tabel 5 diperoleh nilai $F_{\text {hitung }}$ sebesar 17,28 pada lahan pesisir dengan tingkat kepercayaan 95\% $(\alpha=0,05)$. Disini bisa dilakukan pendekatan p-value atau sig., dimana sig. $<\alpha$, maka $\mathrm{H}_{0}$ ditolak dan $\mathrm{H}_{1}$ diterima artinya secara bersama-sama (serempak) variabel lahan; jumlah tanaman produktif; tenaga kerja dan terusi berpengaruh signifikan terhadap produksi kelapa dalam di kabupaten Indragiri Hilir. Dengan kata lain bahwa tanpa adanya input produksi akan mengakibatkan terhentinya proses produksi dan hasil produksi sama dengan nol. Pada tabel juga memberikan informasi bahwa variabel terusi $\left(\mathrm{X}_{4}\right)$ berpengaruh signifikan terhadap produksi kelapa, sedangkan variabel lahan $\left(\mathrm{X}_{1}\right)$; jumlah tanaman produktif $\left(\mathrm{X}_{3}\right)$; dan tenaga kerja $\left(\mathrm{X}_{2}\right)$ tidak berpengaruh signifikan terhadap produksi tanaman kelapa di lahan pesisir.

\section{KESIMPULAN}

Berdasarkan hasil penelitian, maka dapat ditarik kesimpulan sebagai berikut:

1. Produksi petani pada lahan pesisir lebih tinggi dibandingkan dengan lahan yang lainnya, begitupula dengan pendapatan.

2. Faktor yang berpengaruh signifikan terhadap produksi kelapa di lahan gambut pasang surut adalah lahan, jumlah tanaman produktif, dan terusi. Untuk lahan pesisir, faktor yang 
berpengaruh signifikan terhadap produksi adalah terusi, begitupula dengan lahan gambut pesisir. Berbeda dengan lahan daratan, faktor yang berpengaruh signifikan terhadap produksi adalah lahan, tenaga kerja, jumlah tanaman menghasilkan dan terusi.

\section{DAFTAR PUSTAKA}

Abdurachman dan Mulyani. 2003. Kesesuaian Lahan Tanaman Kelapa (Online), (http://www.anakagronomy.com/2013/04/analisis-kesesuaian-lahan-untuk tanaman.html). Diakses pada tanggal 2 Agustus 2018.

Badan Pusat Statistik. 2015. Riau dalam Angka. Propinsi Riau, Pekanbaru.

Badan Pusat Statistik. 2018. Indragiri Hilir dalam Angka. Kabupaten Indragiri Hilir, Tembilahan.

Bavappa, K.V.A S.N. Darwis and D.D. Tarigans. 1995. Coconut Production and Productivity in Indonesia. Asian and Pacific Coconut Community 80pp.

Damanik, S. 2007. Strategi Pengembangan Agribisnis Kelapa (Cocos nucifera) untuk Meningkatkan PendapatanPetani di Kabupaten Indragiri Hilir, Riau Perspektif, 6 (2): 94 $-104$

Dongoran, F. R. 2013. Analisis Keuntungan Usaha Tani Kelapa Di Kecamatan Padangsidimpuan Batunadua. Jurnal Tabularasa PPS Unimed, 10 (2); 151-164.

Gujarati. 1995. Ekonometrika Dasar. Penerbit: Erlangga, Jakarta.

Gujarati. 2001. Ekonometrika Dasar. Penerbit: Erlangga, Jakarta.

Hartawan, R., Arif Sarjono. 2016. Karakteristik Fisik dan Produksi Kelapa Dalam (Cocos nucifera L) di Berbagai Ekologi Lahan. Jurnal Media Pertanian, 1 (2): Hal 45-54

Heriyanto, H., Karya, D., Choanji, T., Asrol, A., Bakce, D., \& Elinur, E. (2019). Regression Model in Transitional Geological Environment For Calculation Farming and Production of Oil Palm Dominant Factor in Indragiri Hilir Riau Province. Journal of Geoscience, Engineering, Environment, and Technology, 4(1), 56-65.

Heriyanto, H., Asrol, A., Karya, D., \& Ningsih, V. Y. (2018). Analisis Faktor Produksi

Kalapa Sawit Rakyat Menurut Tipologi Lahan di Kabupaten Indragiri Hilir Provinsi

Riau. Jurnal Lahan Suboptimal, 7(1).

Mentri Pertanian Republik Indonesia. 2014. Standar Kelapa. www.djppkemenkumham.go.id. Diakses pada tanggal 2 Agustus 2018.

Mustofa, R., Novia Dewi., Jum'atri Yusri. 2016. Analisis Komparasi Usahatani Kelapa Sawit Swadaya Menurut Tipologi Lahan di Kabupaten Indragiri Hilir. Indonesian Journal of Agricultural Economics (IJAE), 7 (1); 47-55

Ngamel, A. K. 2012. Analisis Finansial Usaha Budidaya Rumput Laut Dan Nilai Tambah Tepung Karaginan Di Kecamatan Kei Kecil, Kabupaten Maluku Tenggara. Jurnal Sains Terapan, 2 (1) : 68-83

112 | Kajian Komparasi Produksi Dan Pendapatan Usahatani Kelapa Dalam (Cocos Nucifera Linn) Berdasarkan Tipologi Lahan Di Kabupaten Indragiri Hilir 
Pangkey, M.C., Vecky, A.J. Masinambow., Albert T. Londa. 2016. Perbandingan Tingkat Pendapatan Petani Kelapa di Kabupaten Minahasa Selatan (Studi Kasus di Desa Ongkaw I dan Desa Tiniawangko Kecamatan Sinonsayang). Jurnal Berkala Ilmiah Efisiensi, 16(02): 233-242.

Ruauw, E., Jenny, B., Devison P. 2011. Kajian Pengelolaan Usahatani Kelapa di Desa Tolombukan Kecamatan Pasan Kabupaten Minahasa Tenggara. ASE, 7 (2): 39-50.

Soekartawi. 2003. Teori Ekonomi Produksi dengan Pokok Bahasan Analisis Fungsi CobbDouglas. Penerbit PT. Raya Grafido Persada; Jakarta.

Supandi dan Nurmanaf, A.R. 2006. Pemberdayaan Petani Kelapa dalam Upaya Peningkatan Penddapatan. Jurnal Litbang Pertanian, Hal 26.

Tarigans, D.D. 2005. Diversifikasi Usahatani Kelapa sebagai Upaya untuk Meningkatkan Pendapatan Petani. Perspektif, 4(2): 71-78.

Vaulina, S. dan Saipul Bahri. 2015. Produksi dan Pendapatan Petani Kelapa Dalam (Cocos Nucifera Linn) Di Kabupaten Indragiri Hilir Propinsi Riau. Seminar Nasional "Kristalisasi Paradigma Agribisnis Dalam Pengembangan Ekonomi dan Pendidikan Tinggi”. Bogor.

Wibowo, A. 2007. Budidaya Kelapa. http://insidewinme. blogspot.com /2007 /11/ budidayakelapa.html. Diakses pada tanggal 2 Agustus 2018.

Widarjono, A. 2007. Ekonometrika: Teori dan Aplikasi untuk Ekonomi dan Bisnis Edisi Kedua. Penerbit: Ekonisia Fakultas Ekonomi UII. Yogyakarta.

Yanti, D., Rukavina Baksh., Dance Tangkesalu. 2015. Analisis Pendapatan Dan Kelayakan Usahatani Kelapa Di Desa Malonas Kecamatan Dampelas Kabupaten Donggala. J. Agroland, 22 (1): 76-85 